\title{
Regulation of hepatic metabolism by enteral delivery of nutrients
}

\author{
D. Dardevet ${ }^{1}$, M. C. Moore ${ }^{2}$, D. Remond ${ }^{1}$, C. A. Everett-Grueter ${ }^{2}$ and A. D. Cherrington ${ }^{2 *}$ \\ ${ }^{1}$ Human Nutrition Research Centre of Clermont-Ferrand, F-63122 Ceyrat, France; \\ Institut National de la Recherche Agronomique, Unité de Nutrition Humaine, F-63122 Ceyrat, France \\ ${ }^{2}$ Department of Molecular Physiology and Biophysics, \\ Vanderbilt University School of Medicine, Nashville, TN 37232, USA
}

\begin{abstract}
The liver plays a unique role in nutrient homeostasis. Its anatomical location makes it ideally suited to control the systemic supply of absorbed nutrients, and it is the primary organ that can both consume and produce substantial amounts of glucose. Moreover, it is the site of a substantial fraction (about $25 \%$ ) of the body's protein synthesis, and the liver and other organs of the splanchnic bed play an important role in sparing dietary $\mathrm{N}$ by storing ingested amino acids. This hepatic anabolism is under the control of hormonal and nutritional changes that occur during food intake. In particular, the route of nutrient delivery, i.e. oral (or intraportal) v. peripheral venous, appears to impact upon the disposition of the macronutrients and also to affect both hepatic and whole-body nutrient metabolism. Intraportal glucose delivery significantly enhances net hepatic glucose uptake, compared with glucose infusion via a peripheral vein. On the other hand, concomitant intraportal infusion of both glucose and gluconeogenic amino acids significantly decreases net hepatic glucose uptake, compared with infusion of the same mass of glucose by itself. Delivery of amino acids via the portal vein may enhance their hepatic uptake, however. Elevation of circulating lipids under postprandial conditions appears to impair both hepatic and whole-body glucose disposal. Thus, the liver's role in nutrient disposal and metabolism is highly responsive to the route of nutrient delivery, and this is an important consideration in planning nutrition support and optimising anabolism in vulnerable patients.
\end{abstract}

Hepatic metabolism: Nutrient homeostasis: Glucose: Amino acids: Lipids

\section{Introduction}

After ingestion, nutrients released by the gastrointestinal tract are absorbed and then distributed to tissues for anabolic sequestration. During the postabsorptive phase, without external nutrient intake, they will be released in the bloodstream to maintain adequate supply of nutrients to tissues and organs for maintaining homeostasis. The liver plays a unique role in nutrient homeostasis both because of its anatomical location, which is ideally suited to control the systemic supply of absorbed nutrients, and because it is the primary organ that can both consume and produce substantial amounts of glucose in a net sense. It is also believed that the splanchnic bed plays an important role in sparing dietary $\mathrm{N}$ by storing ingested amino acids. This hepatic anabolism is under the control of hormonal and nutritional changes that occur during food intake. The present review will focus on the importance of the route of macronutrient delivery, i.e. parenteral, or enteral or intraportal, in nutrient metabolism.

\section{Portally delivered glucose: the 'portal signal'}

Work carried out in human subjects (DeFronzo et al. 1978, 1983; Basu et al. 2000) and dogs (Shulman et al. 1978; Cherrington et al. 1979; Barrett et al. 1985; Adkins et al. 1987; Frizzell et al. 1988; McGuinness et al. 1990) demonstrates that neither hyperinsulinaemia nor hyperglycaemia can independently cause much net hepatic glucose uptake. Insulin levels in excess of $6000 \mathrm{pmol} / \mathrm{l}$, when brought about under euglycaemic conditions, were associated with minimal $(4 \mu \mathrm{mol} / \mathrm{kg}$ body weight per $\mathrm{min})$ net splanchnic glucose uptake in human subjects (DeFronzo et al. 1978) and only a modest $(10 \mu \mathrm{mol} / \mathrm{kg}$ body weight per min) net hepatic glucose uptake in the dog (Frizzell et al. 1988). Likewise, increasing the plasma glucose level 2-fold by peripheral intravenous (IV) glucose infusion in the presence of fixed basal amounts of insulin and glucagon caused only slight $(3.3 \mu \mathrm{mol} / \mathrm{kg}$ body weight per min) net splanchnic glucose uptake in human subjects (DeFronzo et al. 1983) and little net hepatic glucose uptake in the dog (Shulman et al. 1978; Adkins et al. 1987).

\footnotetext{
Abbreviations: AMPK, AMP-activated protein kinase; ID, intraduodenal; IV, intravenous; NA, nicotinic acid; TPN, total parenteral nutrition.

*Corresponding author: A. D. Cherrington, fax +1 615343 0490, email alan.cherrington@ Vanderbilt.Edu
} 
Net hepatic glucose uptake remains modest even when hyperinsulinaemia and hyperglycaemia (resulting from glucose infusion into a peripheral vein) are combined. In men the combination of hyperglycaemia $(9.7-12.5 \mathrm{~mm})$ and hyperinsulinaemia (arterial levels of 240-330 pmol/1) resulted in a net splanchnic glucose uptake of $5.6-8.9 \mu \mathrm{mol} / \mathrm{kg}$ body weight per min (DeFronzo et al. 1978, 1983; Basu et al. 2000). Since glucose uptake by the gut accounted for approximately half of that amount, it is clear that little glucose was taken up by the liver, despite the presence of insulin and glucose levels at least as great as those seen after oral glucose consumption. In the dog, with arterial plasma glucose levels of $8.9-16.1 \mathrm{~mm}$ and arterial insulin levels of $210-2304 \mathrm{pmol} / \mathrm{l}$, net hepatic glucose uptake ranged from 5.6 to $16.1 \mu \mathrm{mol} / \mathrm{kg}$ body weight per min (Cherrington et al. 1982; Ishida et al. 1983; Barrett et al. 1985; Adkins-Marshall et al. 1990) such that the magnitude of the response correlated with the load of glucose and insulin presented to the liver.

Assessment of glucose uptake by the liver after oral glucose consumption in human subjects is problematic because of the difficulty in obtaining hepatic and portal vein blood samples. It is now known that some of the assumptions (for example, the duration of absorption) in the early splanchnic balance studies of Felig et al. (1975, 1978) were flawed, leading to overestimates of the role of the liver in oral glucose disposition. Studies based on more accurate assumptions have suggested that about one-quarter to one-third of an oral glucose load is extracted by the liver (Ferrannini et al. 1985; Kawamori et al. 1994) with the peak rate of net hepatic glucose uptake equaling 27.8-44.4 $\mu \mathrm{mol} /$ $\mathrm{kg}$ body weight per min. Using ${ }^{13} \mathrm{C}$ NMR, Cline et al. (1994) estimated the liver glycogen synthetic rate in man to be about $0.5 \mu \mathrm{mol} / \mathrm{ml}$ liver per min, a value consistent with the observed splanchnic glucose uptake rates noted earlier. In general, studies carried out with tracer methodology in human subjects have shown that up to $10 \%$ of an oral glucose load is extracted by the liver on first pass, a finding consistent with the overall contribution of the liver to glucose storage (i.e. including the glucose extracted on subsequent passes) being about 25-35\% (Pehling et al. 1984; Firth et al. 1986; Benn et al. 1989; Radziuk, 1989; Kelley et al. 1994; Mari et al. 1994).

The dog has proven a very useful model in examination of the response of the liver to glucose because catheters can be placed in the hepatic and portal veins and the role of the liver can be directly assessed. A number of investigators have quantified the fate of orally delivered glucose in this species (Abumrad et al. 1982; Bergman et al. 1982; Ishida et al. 1983; Barrett et al. 1985, 1994; Moore et al. 1991). These studies have collectively provided direct support for the conclusions drawn from studies done in human subjects. In the dog, over the absorptive period, the liver accounted for the uptake of $25-40 \%$ of the administered glucose. Further, the peak rates of net hepatic glucose uptake were 16.6$40 \mu \mathrm{mol} / \mathrm{kg}$ body weight per min in the presence of elevated arterial insulin $(240-558 \mathrm{pmol} / \mathrm{l})$ and glucose $(7 \cdot 8-10 \cdot 3 \mathrm{~mm})$ concentrations, respectively. It is clear from these studies that, when the insulin level is increased 4- to 6-fold and the hepatic glucose load is increased to 2fold basal by oral glucose consumption, net hepatic glucose uptake is approximately $30 \mu \mathrm{mol} / \mathrm{kg}$ body weight per min. There is thus no doubt that the liver takes up two to three times as much glucose following oral glucose ingestion as it does under similar hyperglycaemic and hyperinsulinaemic conditions in the presence of peripheral glucose infusion.

The ability of combined changes in insulin and glucose to cause greater hepatic glucose uptake when they are associated with oral glucose delivery led DeFronzo et al. (1978) to propose the existence of a gut factor, released in response to oral glucose intake, which could augment net hepatic glucose uptake. Since the proposition of this gut factor, a number of studies have cast doubt on its importance. Bergman et al. (1982), Ishida et al. (1983) and Barrett et al. (1985) bypassed the gut and produced hyperglycaemia via an intraportal glucose infusion that mimicked the absorption profile of oral glucose. In their studies net hepatic glucose uptake was the same after intraportal and oral glucose entry (mean rates for portal $v$. oral delivery: 13.9 v. $12.8,33.3$ v. 30.0 , and 31.6 v. $30.0 \mu \mathrm{mol} / \mathrm{kg}$ body weight per min, respectively). These data ruled out a gut factor and led to the hypothesis that the liver responds differently to portal than to peripheral delivery of glucose. Thus the 'gut factor' was, in fact, a 'portal factor'. The first well-controlled direct demonstration of a portal effect in vivo came from Adkins et al. (1987) using the conscious dog. In the presence of somatostatin (used to gain control of the endocrine pancreas) insulin and glucagon were fixed at basal values and hyperglycaemia $(12.2 \mathrm{~mm})$ was brought about by peripheral glucose infusion. Net hepatic glucose output fell to near zero, but the liver failed to exhibit net glucose uptake. With the same glucose load, but in the presence of portal glucose delivery, there was significant net hepatic glucose uptake $(7.8 \mu \mathrm{mol} / \mathrm{kg}$ body weight per min) such that the liver took up $32 \%$ of the intraportally delivered glucose load. Our laboratory subsequently established that portal glucose delivery was associated with significantly greater net hepatic glucose uptake in the presence of both eu- and hyperinsulinaemia and across a wide span of physiological hepatic glucose loads (Fig. 1). Interestingly, whole-body glucose clearance did not change, suggesting not only that the liver became more efficient in its disposal of glucose but that the muscle became less efficient; later studies confirmed that glucose uptake by non-hepatic tissues declined in the presence of portal glucose delivery (Galassetti et al. 1998, 1999; Hsieh et al. 1998, 1999). Further, using the limb balance technique in the conscious dog, it was shown that skeletal muscle was the site of this inhibition (Galassetti et al. 1998). Thus in response to portal glucose delivery the role of the liver in glucose clearance is increased, while the role of muscle is decreased. A signal generated by portal glucose delivery (the portal glucose signal), therefore, ensures that an oral glucose load is appropriately distributed between the skeletal muscle (35$45 \%)$, the liver $(25-35 \%)$ and the other tissues of the body (30\%) (Cherrington, 1999).

The nature of the signal that might modulate hepatic and skeletal muscle glucose uptake simultaneously is unclear as yet, but possible candidates are neural networks and/or humoral mediators (Lautt, 2004; Puschel, 2004). Whatever the nature of the signal, the hypothalamus is likely to be 


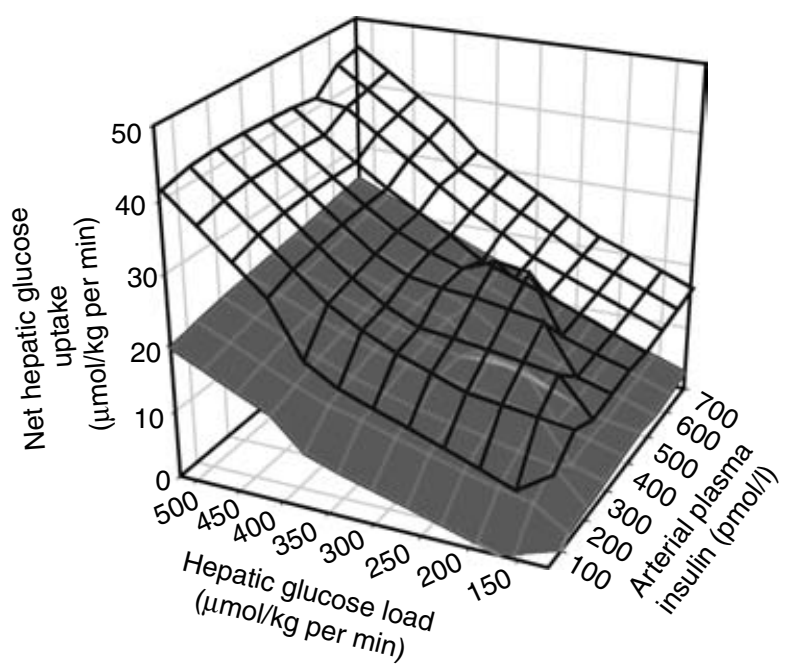

Fig. 1. At any physiological plasma insulin concentration and hepatic glucose load examined, net hepatic glucose uptake is approximately 2- to 3-fold greater with portal $(\square) v$. peripheral $(\square)$ venous infusion of glucose. (Data compiled from Myers et al. 1991a,b; Pagliassotti et al. 1996; Galassetti et al. 1998; Hsieh et al. 1998, 1999; Moore et al. 1998.)

involved in its integration. Afferent signals from the liver are conducted to the hypothalamus by the vagus nerve, with the afferent firing rate in the hepatic branch of the vagus being inversely proportional to the glucose concentration in the portal vein (Niijima, 1982). Stimulation of ventromedial hypothalamic signalling, in turn, has been shown to enhance muscle glucose uptake, an effect that can be prevented with sympathetic blockade (Minokoshi et al. 1994). In addition to receiving neural signals from the periphery, the hypothalamus is sensitive to circulating hormones and substrates, including insulin and glucose. In mice, intracerebroventricular infusion of insulin (with no increase in circulating insulin concentrations) significantly enhanced muscle glycogen synthesis and whole-body glucose turnover in the basal state (Perrin et al. 2004). On one hand, intracerebroventricular glucose infusion in the basal state did not alter muscle glycogen synthesis. However, intracerebroventricular glucose infusion during a hyperinsulinaemic-euglycaemic clamp markedly reduced the insulin-stimulated muscle glycogen synthesis without changing whole-body glucose turnover. Intracerebroventricular injections of insulin and the AMP-activated kinase activator 5-aminoimidazole-4carboxamide-1- $\beta$-D-ribofuranoside were found to increase the phosphorylation state of AMP-activated protein kinase (AMPK) 40-80\%, while glucose injection reduced phosphorylation of AMPK 50\%. When insulin and glucose were injected together, glucose completely inhibited the effect of insulin on AMPK phosphorylation. Insulin and glucose are known to enter the brain from the circulation. Evidence indicates that cerebral AMPK plays a role as an energy sensor; thus, by modulating the phosphorylation of AMPK, insulin and glucose may play a role in muscle glucose disposal (Perrin et al. 2004).

Most studies of the portal signal have focused on the acute (i.e. postprandial) state, but evidence suggests that it also functions in the chronically adapted state. When dogs received either total parenteral nutrition (TPN) or TPN with a portion of the glucose infused enterally (TPN + enteral glucose group; total energy delivery being the same between groups) for $5 \mathrm{~d}$, net hepatic glucose uptake and arterial glucose and insulin concentrations did not differ in the TPN and TPN + enteral glucose groups. Nevertheless, glucose uptake by the non-hepatic tissues was significantly reduced in the TPN + enteral glucose $v$. TPN groups (Chen et al. 2005).

The importance of the route of glucose delivery in man has been more difficult to evaluate because of an inability to catheterise the portal vein and the difficulty in controlling the insulin and glucagon levels reaching the liver. Early work by DeFronzo et al. (1978) showed that oral glucose ingestion augmented net splanchnic glucose uptake (a 6fold increase). Nevertheless, the design of their study was such that the liver was exposed to a larger hepatic glucose load and higher insulin levels in the group receiving oral glucose. How much of the augmented hepatic response was attributable to those parameters rather than the portal glucose signal per se is not clear, but from what we now know (for example, Myers et al. 1991a,c), it was probably less than half. Recent work by Vella et al. (2002), in which a pancreatic clamp was used to fix the hormonal milieu during IV or intraduodenal (ID) glucose infusion, led to the conclusion that ID glucose increased hepatic glucose extraction by 50 to $100 \%$. This conclusion was reached despite a technical flaw (ID infusion of tracer glucose without cold glucose carrier in the IV group) which would have falsely elevated the apparent uptake of glucose by the liver in the IV group. These authors failed to detect a difference in hepatic glycogen deposition (measured using the glucuronide technique), but this is not surprising given the small rise in glucose they brought about, the size of the arterial-portal glucose gradient they used, and the fraction of extracted glucose that normally is deposited in glycogen.

Fery et al. (2001) showed that the effects of IV and ID glucose on whole-body glucose kinetics in human subjects were not different. The fact that there was no difference in whole-body glucose kinetics is consistent with findings in the dog (Galassetti et al. 1998, 1999; Hsieh et al. 1998, 1999). As net hepatic glucose uptake is enhanced during portal glucose delivery in the dog, skeletal muscle glucose uptake decreases in a reciprocal manner, leaving wholebody glucose disposal unchanged. Even though this portion of the human findings agree with those in the dog, however, the conclusions that can be drawn from the human study are limited (Fery et al. 2001). The insulin and glucose levels were not controlled, and these parameters differed markedly between the two routes of delivery. Also, the study did not identify the primary site(s) (liver $v$. muscle) of glucose uptake. In a more recent study (Fery et al. 2004) the same investigators used tracer methods to compare the effects of IV and ID glucose infusion on first-pass splanchnic glucose uptake under euglycaemic conditions. They concluded that their data do not support the existence of the portal signal in man, but three points should be considered. First, the study was carried out under euglycaemic conditions, which minimise the role of the liver. Second, the glucagon levels were not controlled and were higher in the ID group, which would be expected to suppress hepatic glucose uptake (Holste et al. 1997), and finally their estimate of first-pass 
hepatic extraction in the ID group, which was calculated as the difference between the glucose infusion rate and rate of appearance of the infused glucose, was error prone. This is underscored by the data from their IV group (i.e. a group in which no first-pass extraction occurred), which showed a greater first-pass extraction than did their ID group $(2 \cdot 1 \mathrm{v}$. $1.7 \mu \mathrm{mol} / \mathrm{kg}$ body weight per min). Clearly the majority of evidence supports the concept that a portal signal is functional in man, but well-controlled studies definitively proving the concept are still lacking.

It has been recognised for a number of years that oral glucose ingestion results in an enhanced insulin response, in comparison with the response to the same glucose load given intravenously (Nauck et al. 1986). Portal glucose delivery apparently creates a similar incretin effect. When glucose was infused either peripherally or intraportally to clamp the arterial plasma glucose concentration at the same level of hyperglycaemia, plasma insulin concentrations were significantly enhanced by portal glucose delivery (Dunning et al. 2002). The reflex increase in vagal pancreatic efferent firing that results from intraportal glucose delivery (Niijima, 1983, 1984) probably helps to explain this phenomenon.

A role for the central nervous system in the response to portal glucose delivery is supported by the literature. In the late 1960s Russek $(1963,1981)$ proposed that afferent signals originating in the liver might play a part in appetite control. Schmitt (1973) subsequently identified lateral hypothalamic neurons which changed their firing rate upon the injection of glucose into the portal vein. Additionally, Niijima (1982, 1985) reported the existence of afferent fibres in the hepatic branch of the vagus nerve which exhibited a discharge rate inversely related to the glucose concentration in the portal vein. Both Schmitt and Niijima noted that the changes in neural firing were specific to glucose and established the fact that the brain receives input regarding the portal glucose level. Work by a number of investigators (for example, Lautt, 1983; Shimazu, 1987; Stumpel \& Jungermann, 1997) has clearly established the potential of sympathetic and parasympathetic signalling to regulate liver glucose metabolism. Interestingly, Shimazu (Shimazu, 1967, 1971; Shimazu \& Fujimoto, 1971) reported that electrical stimulation of the vagus nerve activated glycogen synthase and enhanced incorporation of $\left[{ }^{14} \mathrm{C}\right]$ glucose into liver glycogen in both intact and pancreatectomised rabbits. In vivo work provided further support by showing that atropine decreased net hepatic glucose uptake following oral glucose ingestion in dogs (Chap et al. 1985), although hormone levels were not controlled, making it unclear whether the effect on the liver was direct or indirect. Moreover, Adkins-Marshall et al. (1992) demonstrated that the portal glucose signal cannot trigger increased glucose uptake in vivo in the chronically denervated liver. Intraportal infusion of acetylcholine, on the other hand, was able to augment net hepatic glucose uptake under hyperglycaemichyperinsulinaemic conditions in the absence of the portal glucose signal (Shiota et al. 2000). In addition, Stumpel \& Jungermann (1997) showed that atropine could block the effect of the portal glucose signal in the perfused rat liver. Unfortunately there are significant limits to conclusions that can be drawn from these studies. First, chronically denervated livers lack both sympathetic and parasympathetic input, as well as both afferent and efferent pathways, and the interval between surgery and experiment undoubtedly results in adaptive changes. Attempting to mimic parasympathetic activation by portal acetylcholine infusion stimulated net hepatic glucose uptake in the dog, but it also caused a marked increase in hepatic artery blood flow (Shiota et al. 2000). This raises the possibility that the parasympathetic nervous system (or at least the classical neurotransmitter acetylcholine) is not the effector limb of the effects caused by portal glucose delivery. In another series of experiments, cooling the vagus nerves during portal glucose delivery had no impact on net hepatic glucose uptake despite the fact that the increase in heart rate confirmed that cooling had blocked vagal transmission (Cardin et al. 2004). Therefore, despite this evidence, definitive data establishing a physiological role for the parasympathetic nerves in the regulation of liver glucose uptake in vivo are still lacking. On the other hand, selective sympathectomy of the liver in the dog enhanced net hepatic glucose uptake during peripheral glucose infusion about $70 \%$ but did not stimulate net hepatic glucose uptake during portal glucose delivery (DiCostanzo et al. 2006). This suggests that the basal sympathetic input to the liver is inhibitory to glucose uptake, and portal glucose delivery relieves the inhibition. Whether a stimulatory limb of the portal signal exists remains undetermined.

Using ${ }^{13} \mathrm{C}$ NMR Shulman et al. (1987) demonstrated in the rat that the glycogen synthetic rate was 2.5 times greater following oral as opposed to IV glucose administration, even when glucose and insulin levels were equivalent. We showed that under hyperglycaemic conditions the portal glucose signal increased the percentage of glycogen synthase in the active form even in the absence of a concomitant rise in insulin. This activation was associated with a significant increase in glycogen deposition (Pagliassotti et al. 1996). Whether the activation of glycogen synthase represents a direct effect of the portal signal or whether it occurred secondary to an increase in glucose-6-phosphate is unclear (Bollen et al. 1998). It appears that about two-thirds of the glucose taken up by the liver in response to the portal signal is stored as glycogen and one-third exits in the liver as lactate (Moore et al. 2004). While the portal glucose signal increased glycogen deposition, it did not alter the percentage of net hepatic glucose uptake that was directed to glycogen. This suggests that it must affect either the movement of glucose into the hepatocyte and/or its phosphorylation once it is inside the cell. Glut 2 transporters in the liver have been shown to be hormone and glucose sensitive, but the observed modifications occur slowly (Andersen et al. 1994; Weinstein et al. 1994; Bollen et al. 1998), so an effect on glucose transport is unlikely to provide an explanation for the effect of the portal signal since the latter occurs very quickly (Pagliassotti et al. 1996). Studies by Liu et al. (1993), van Schaftingen (Detheux \& van Schaftingen, 1994; van Schaftingen, 1994) and Agius (Agius \& Peak, 1993; Agius, 1994), on the other hand, support the possibility of rapid modification of glucokinase activity. It is now known that glucokinase is acutely regulated by binding to a regulatory protein which is sequestered in the nucleus. Glucokinase is dissociated from the regulatory protein by fructose-1-phosphate; thus the 
latter serves to activate the enzyme. This explains the ability of low levels of fructose to augment net hepatic glucose uptake (Shiota et al. 1998). Glucose, and to a lesser extent insulin, have been shown to cause the translocation of glucokinase from the nucleus to the cytoplasm of the hepatocyte (Chu et al. 2004). Given the similarity in the disposition of glucose taken up by the liver in response to fructose and the portal glucose signal, the question arises as to whether translocation of glucokinase represents the mechanism by which the latter augments net hepatic glucose uptake. Preliminary data indicate that this is likely to be the case (Cherrington, 1999).

\section{Towards a portal amino acid signal?}

During the day, protein metabolism is modified by food intake. In adult human subjects, oral feeding is associated with an increase of whole-body protein synthesis and a decrease of proteolysis (Rennie et al. 1982; Pacy et al. 1994; Boirie et al. 1996; Volpi et al. 1996; Arnal et al. 2000). Since the whole-body protein mass remains constant from day to day, the gain of protein during the postprandial period is cancelled by a loss of protein in the postabsorptive state. These changes in protein metabolism are mediated by feeding-induced increases in plasma concentrations of both nutrients and hormones.

Many studies suggest that amino acids and insulin play major roles in promoting postprandial protein anabolism. In human subjects, the effect of feeding on protein metabolism is correlated with the amount of protein intake: whole-body protein synthesis is further stimulated and protein degradation is further inhibited when the protein content of the diet is increased from 0.36 to $2.77 \mathrm{~g} / \mathrm{kg}$ per d (Pacy et al. 1994). On the other hand, feeding a protein-free diet does not stimulate protein synthesis despite a significant postprandial rise in plasma insulin (Volpi et al. 1996). These observations showed the essential role of amino acids in the postprandial increase in whole-body protein anabolism in human subjects.

In rodent skeletal muscles, a rise in plasma insulin without dietary amino acid supply does not promote protein anabolism (Yoshizawa et al. 1998), and provision of exogenous insulin to freely fed rodents does not increase protein synthesis beyond the effect of refeeding (Garlick et al. 1983; Svanberg et al. 1997). In fact, recent studies have shown that suppression of a postprandial increase in insulin greatly decreases protein synthesis in adult and old rat muscles, irrespective of the nutritional condition, suggesting that amino acids and insulin interact in promoting postprandial protein anabolism (Balage et al. 2001; Prod'homme et al. 2004). Both insulin and amino acids have been shown to regulate the mammalian target of rapamycin pathway in muscle, thus regulating protein synthesis, and maximal activation is achieved only when both factors are appropriately altered (Bolster et al. 2004). However, conversely to what is observed in adults, it seems that, in the neonate, the stimulation of muscle protein synthesis by insulin and amino acids is independent and thus stimulation by amino acids does not require insulin (Davis et al. 2002; O'Connor et al. 2003a,b). These examples suggest that, as for whole-body protein metabolism, amino acids play a key role in the determination of the level of postprandial protein metabolism in skeletal muscle, and insulin plays a secondary role.

Although skeletal muscle is clearly an important protein synthetic site, organs of the splanchnic bed (liver and gut) account for $25 \%$ of whole-body protein synthesis (Barle et al. 1997). Of the protein synthesised in the liver, $40 \%$ is secreted, with albumin alone accounting for almost half of it. Conversion of dietary amino acids to albumin is thought to provide a means of storing protein; indeed albumin can be broken down during periods of nutrient deprivation to provide essential amino acids for protein synthesis (De Feo \& Lucidi, 2002). Following a mixed meal, the liver is exposed to high levels of amino acids and insulin. In adult human subjects, increasing amino acid levels by IV infusion results in an increase in protein synthesis across the splanchnic bed (Nygren \& Nair, 2003). This effect is evident in the presence of basal insulin levels, suggesting that elevation of this hormone is not essential for an increase in splanchnic bed protein synthesis. Splanchnic metabolism includes both gut and hepatic metabolism, for which regulation pathways could be different. Indeed, studies conducted in mature animals with IV infusion of amino acids have shown that amino acids and insulin have no stimulatory effect on mixed liver protein synthesis (Mosoni et al. 1993; Ballmer et al. 1995; Ahlman et al. 2001). Conversely, in the neonate, hepatic protein synthesis can be stimulated by raising amino acid levels (Yoshizawa et al. 1997). These studies raise the questions of whether or not amino acids stimulate hepatic protein synthesis and, if so, whether this effect is age-dependent.

It has been previously observed that ageing is associated with a decline in the anabolic response of skeletal muscle to food intake and amino acids (Mosoni et al. 1995; Dardevet et al. 2000, 2002). Similarly, Davis et al. (2002) have observed a developmental decline in amino acid-induced stimulation of hepatic protein synthesis in the growing animal. From these studies, one might infer that there is a decreased sensitivity of the liver to amino acids during ageing. However, this inference is inconsistent with findings in adult human volunteers, in which dietary amino acids have been shown to increase hepatic export protein synthesis, i.e. albumin (De Feo et al. 1992; Hunter et al. 1995; Volpi et al. 1996; Cayol et al. 1997). It is important to note that one difference between the animal and human studies cited is the route of administration of amino acids: peripherally $v$. orally, respectively. This difference led us to hypothesise that, in the mature organism, the route of delivery of amino acids is critical in the stimulation of hepatic protein synthesis. In support of this hypothesis, human studies have shown that albumin synthesis is stimulated with oral meal feeding whereas it is not responsive to IV nutrients (Ballmer et al. 1995; Hunter et al. 1995). Moreover, it is now well established that splanchnic tissues extract, on first pass, a significant amount of dietary amino acids (Burrin \& Davis, 2004). Of enterally administered amino acids, 20 to $96 \%$ are utilised by the splanchnic bed, showing the crucial role of the splanchnic tissues in the distribution and availability of dietary amino acids to peripheral tissues (Ferrannini et al. 1988; Biolo et al. 1992; Matthews et al. 1993; Burrin \& Davis, 2004). Dietary 
amino acids are the preferential source of substrate for small intestine and hepatic protein synthesis (Berthold et al. 1995; Cayol et al. 1996; Stoll et al. 1998). Enhanced splanchnic extraction of amino acids has been suspected to be responsible for the defect in the postprandial stimulation of muscle protein synthesis during ageing (Boirie et al. 1997; Volpi et al. 1999). Interestingly, recent studies conducted in piglets show that the dietary requirements for lysine, methionine, leucine, valine, isoleucine, and threonine (based on the indicator amino acid oxidation technique) are lower with TPN than with enteral nutrition (Bertolo et al. 1998; House et al. 1998; Elango et al. 2002; Shoveller et al. 2003; Burrin \& Davis, 2004). These data illustrate the increased demand for amino acids by the digestive tract, pancreas, and the liver in orally fed animals. Portal vein blood flow accounts for $75 \%$ of the total hepatic blood flow, and, during the postprandial state, the amino acid concentrations are higher in portal vein blood than in hepatic artery blood (Moore et al. 1994). The enhanced utilisation of orally delivered amino acids by the liver may thus be the result of increased amino acid availability when compared with the parenteral amino acid administration.

Another possibility is that the portal (or dietary) delivery of amino acids is able to initiate a signal to the liver that increases hepatic metabolism. The results of several studies (Moore et al. 1998, 1999a,b) conducted in our laboratory are consistent with an amino acid-initiated portal signal when delivered directly into the portal vein; this signal appears to be distinct from, but to interact with, the portal glucose signal.

Not only does the route of amino acid delivery appear to impact on amino acid utilisation in the splanchnic bed, but it also appears to affect glucose disposal. We undertook a series of studies to examine the role of amino acids and their route of delivery (peripheral vein $v$. portal vein infusions) on net hepatic glucose uptake in the conscious dog. In the presence of a fixed hormonal milieu $(4 \times$ basal insulin; $1 \times$ basal glucagon) and a portal glucose infusion, we found (Moore et al. 1998) that portal gluconeogenic amino acid infusion reduced net hepatic glucose uptake (Fig. 2) and net hepatic glycogen synthesis by 50 and $30 \%$ respectively. This decrease could have originated from the hepatic amino acid load itself (i.e. competition between substrates for hepatic extraction) or it could be specific to the intraportal route of amino acid delivery by activation of a neural signal initiated by contact between hepatoportal sensors and the amino acids. To answer this question, we studied a group of dogs under identical conditions to our previous study except that the gluconeogenic amino acids were delivered peripherally at a rate that would maintain hepatic amino acid load equivalent to that evident in our previous study (Moore et al. 1999a). Under these conditions, and in contrast to the portal delivery, peripheral delivery of the amino acids did not reduce net hepatic glucose uptake initiated by the portal glucose delivery. This observation is thus consistent with the hypothesis that intraportal delivery of amino acids generates a signal that competes with or modulates the signal that enhances net hepatic glucose uptake during portal glucose delivery. From these studies, it can be speculated that intraportal amino acid infusion not only modulates net hepatic glucose uptake but also

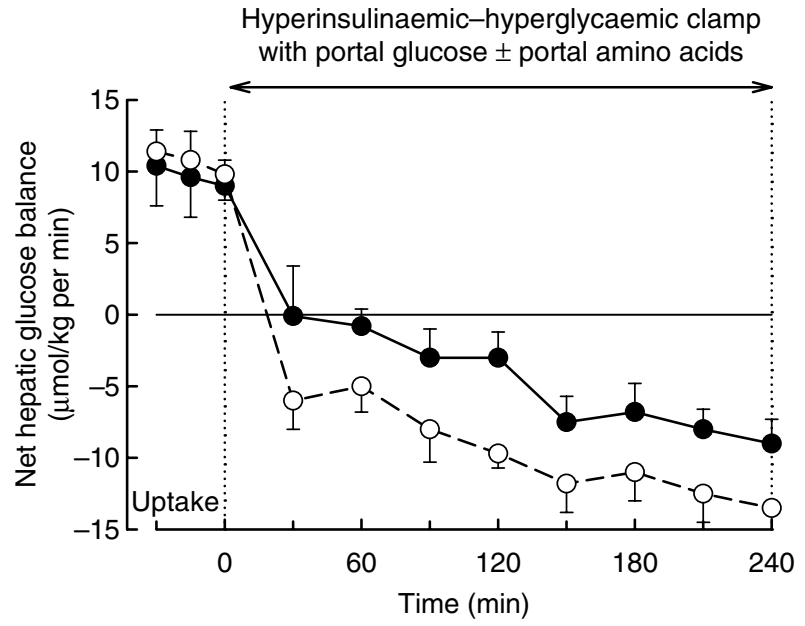

Fig. 2. Net hepatic glucose balance under basal conditions and during a pancreatic clamp with infusion of somatostatin to suppress endocrine pancreatic secretion, intraportal infusion of insulin and glucagon at 4-fold basal and basal rates, respectively, and intraportal and peripheral infusion of glucose to elevate the hepatic glucose load 1.5-fold basal. One group received an intraportal infusion of a gluconeogenic amino acids mixture $(--)$, while the other received an intraportal saline infusion without amino acids (-०-). Data are means, with standard errors represented by vertical bars. Differences between groups were significant $(P<0.05)$. (Reprinted with permission from Moore et al. 1998.)

modulates hepatic uptake and utilisation of the amino acids. To test this hypothesis, we initiated another protocol under the same conditions as described earlier (i.e. intraportal replacement of insulin at a 4-fold basal rate and glucagon at a basal rate, and hepatic glucose load 1.5fold basal), except that glucose was infused peripherally to avoid any potential interaction of the amino acids with the glucose portal signal. Gluconeogenic amino acids were infused peripherally or intraportally; the infusion rates were adjusted to match the hepatic load of the amino acids between the two groups (Moore et al. 1999b). The net hepatic uptake of glutamine (Fig. 3) and the net fractional extractions of glutamine and serine were significantly increased during the portal vein administration of amino acids. These observations are consistent with a portal amino acid signal independent of the portal glucose signal that is able to alter hepatic amino acid utilisation itself.

Our studies were limited to the gluconeogenic amino acids; and thus the next question was: could these observations be generalised for other amino acids? With the peripheral amino acid infusion, the net hepatic uptake of glucose and amino acids (in carbon equivalents) is very similar to the net hepatic glycogen deposition and lactate release. With the portal amino acid infusion, only $70 \%$ of the carbon taken up by the liver could be accounted for by glycogen synthesis and lactate release. Thus, the fate of the remaining $30 \%$ of carbon remains unknown. Nevertheless, it is very tempting to hypothesise that the portal amino acid signal also directed the amino acids into protein synthesis. Whether portal amino acids modulate the activity of the autonomic nervous system to increase hepatic protein synthesis is unknown. However, Niijima \& Meguid (1994, 1995) have described hepato-portal sensors for fifteen 


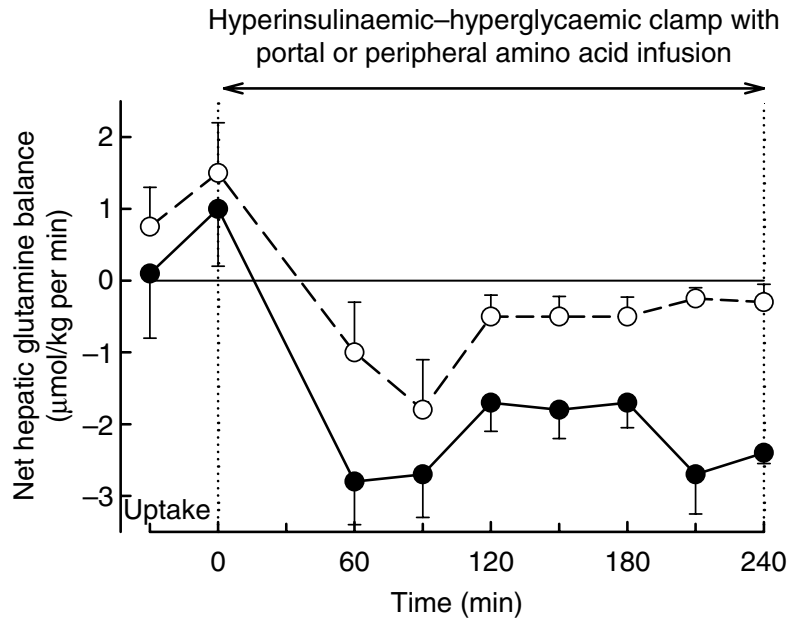

Fig. 3. Conscious dogs were studied during a pancreatic clamp, with insulin and glucagon infused at 4-fold basal and basal rates, respectively, and the hepatic glucose load increased to 1.5 -fold basal by peripheral glucose infusion. A gluconeogenic amino acid mixture was infused via the hepatic portal vein $(-\bullet-)$ or a peripheral vein $(-$ $\bigcirc-$ ). Data are means, with standard errors represented by vertical bars. Net hepatic glutamine uptake was enhanced during portal $v$. peripheral infusion of gluconeogenic amino acids $(P<0.05)$. (Reprinted with permission from Moore et al. 1999b.)

different amino acids that modulate the afferent firing rate of the hepatic branch of the vagus nerve. The involvement of neuronal input in controlling liver metabolism has already been shown with another nutrient, i.e. glucose (see pp. 161-165). Niijima \& Meguid (1995) delineated amino acids (AA) serving as stimulators (AA + : alanine, arginine, histidine, leucine, lysine, serine, tryptophan, valine) and inhibitors (AA-: cysteine, glycine, isoleucine, methionine, phenylalanine, proline, threonine) of the vagal afferent discharge rate. Moreover, Watanabe et al. (1990) postulated that plasma protein synthesis is enhanced by vagal-nerve stimulation. Whether portal amino acids modulate the activity of the autonomic nervous system to increase hepatic protein synthesis is unknown and has to be further studied.

\section{Impact of lipids on hepatic and whole-body glucose uptake and insulin sensitivity}

NEFA concentrations normally fall during the postprandial period, but concentrations in individuals with type 2 diabetes remain higher than in non-diabetic controls (Reaven et al. 1988; Reaven, 2005). Net splanchnic glucose uptake following glucose or meal ingestion is reduced in individuals with type 2 diabetes, primarily because of an increase in splanchnic glucose output, relative to that in normal volunteers (Ludvik et al. 1997; Woerle et al. 2006). There is abundant evidence that elevated circulating NEFA impair insulin-mediated suppression of endogenous glucose production (for example, Sindelar et al. 1997; Boden et al. 2002; Homko et al. 2003), and thus the question arose as to the effect of elevated NEFA on postprandial hepatic glucose disposal.

We carried out a group of studies in the conscious dog to examine the effect of maintaining NEFA at their basal concentrations under conditions mimicking those in the postprandial state (Moore et al. 2004). Arterial plasma NEFA concentrations under basal conditions were about $900 \mu \mathrm{mol} / \mathrm{l}$. After basal sampling, the dogs underwent a $4 \mathrm{~h}$ pancreatic clamp, with insulin and glucagon infused intraportally at basal rates, glucose infused intraportally to mimic postprandial absorption, and glucose infused via a peripheral vein as needed to stabilise the hepatic glucose load at 2-fold basal. Nicotinic acid (NA) was infused via a peripheral vein to suppress lipolysis. After the initial $2 \mathrm{~h}$ of the clamp period (period 1), the dogs were divided into three groups for an additional $2 \mathrm{~h}$ of study (period 2). During period 2, all infusions continued as during period 1. One group (NA group) continued exactly as in period 1 ; another group (NA + lipid group) received a peripheral venous infusion of $20 \%$ lipid emulsion to increase arterial NEFA concentrations to their basal level, and the third group (NA + glycerol group) received a glycerol infusion to elevate circulating glycerol concentrations to the same levels observed in the NA + lipid group. There were no significant differences in glucose metabolism between the $\mathrm{NA}$ and NA + glycerol groups. However, the rate of net hepatic glucose uptake in the NA + lipid group during period 2 was $<50 \%$ of that in the other two groups (Fig. 4). In the NA and NA + glycerol groups, endogenous glucose rate of appearance was suppressed by about $85-90 \%$ by the end of study, while it was reduced only by about $33 \%$ in the NA + lipid group. Moreover, intrahepatic disposition of the glucose extracted by the liver was altered by the elevation of NEFA. Hepatic glucose oxidation in the NA + lipid group was only $54 \%$ of that in the NA group during period $2(P<0 \cdot 05)$. Also, the suppression of NEFA appeared to direct glucose toward glycolysis; in the NA and $\mathrm{NA}+$ glycerol groups, net hepatic lactate output was maintained throughout period 2, while the NA + lipid group shifted to net hepatic uptake of lactate (Fig. 4). As a consequence of these differences in glucose oxidation and glycolysis, similar amounts of carbon were retained within the livers in all three groups, and measured glycogen synthesis was not different among groups.

These findings in the acute 'postprandial' setting prompted us to examine the effect of chronic postprandial NEFA elevation, as seen in type 2 diabetes, on hepatic and peripheral insulin sensitivity. In this case, a lipid infusion was delivered intraportally in an effort to mimic the conditions in individuals with increased visceral adiposity. Visceral adipose tissue releases NEFA into the portal vein, and suppression of lipolysis in the visceral adipose is poorly responsive to insulin (Meek et al. 1999). Visceral adiposity has been implicated in the development of inflammation and steatohepatitis (for a review, see Scheen \& Luyckx, 2002). In one investigation, omentectomy at the time of adjustable gastric banding was associated with improved insulin sensitivity 2 years later, compared with gastric banding alone (Thorne et al. 2002). Therefore, for $15 \mathrm{~d}$, dogs received infusions of a $20 \%$ lipid emulsion or saline into the hepatic portal circulation for $3 \mathrm{~h}$ in the immediate postprandial period following their single daily meal (Everett et al. 2005). On the sixteenth day, after an overnight fast, the dogs underwent a two-step hyperinsulinaemic-euglycaemic clamp. After an initial period of basal sampling, somatostatin 

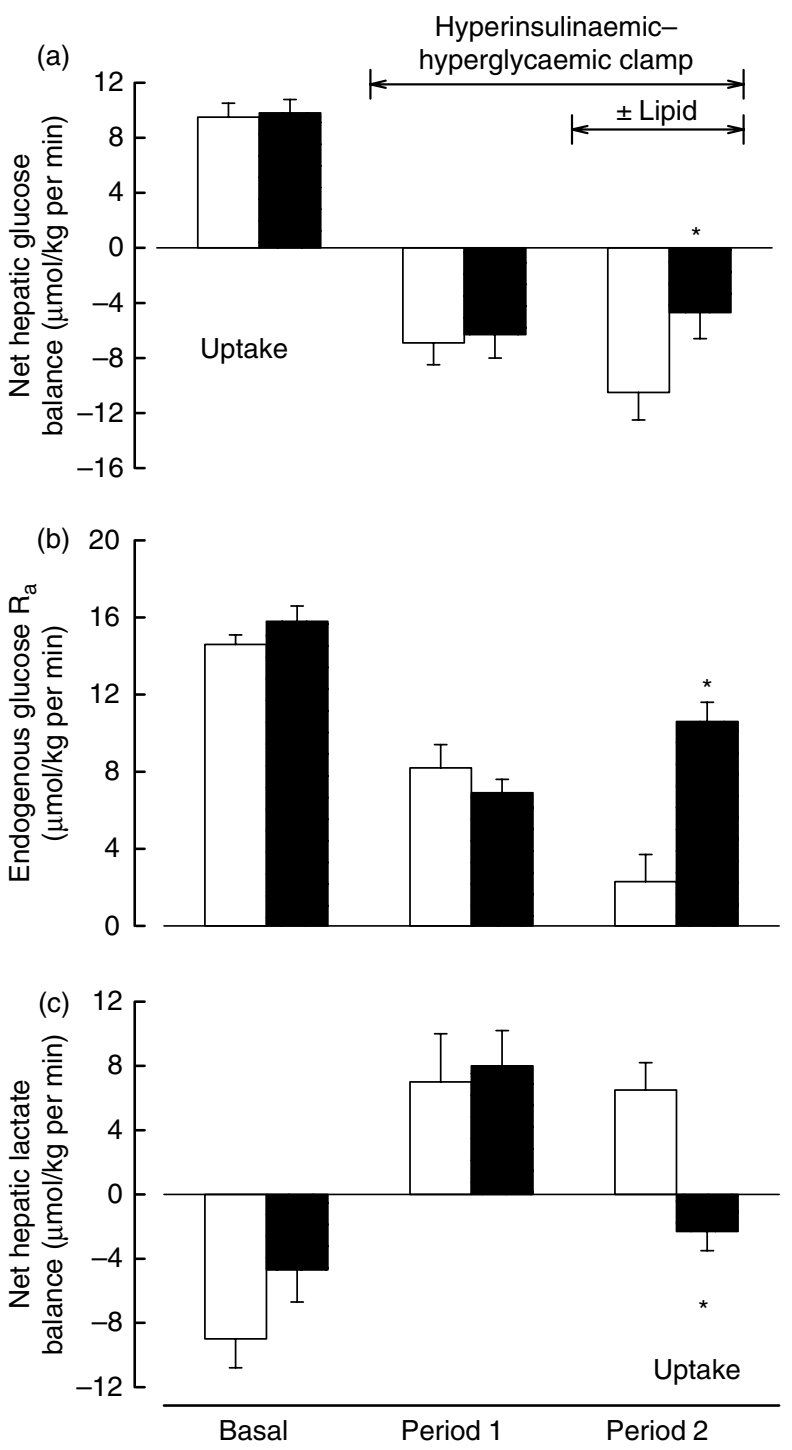

Fig. 4. Net hepatic glucose balance (a), endogenous glucose rate of appearance $\left(R_{a}\right)(b)$ and net hepatic lactate balance (c) under basal conditions and during a hyperinsulinaemic-hyperglycaemic clamp. During periods 1 and 2, all animals received a peripheral infusion of nicotinic acid (NA; $\square$ ). During period 2, one group (NA + lipid group) also received an infusion of a long-chain lipid emulsion ( $\square$ ); another group (NA + glycerol) received an infusion of glycerol at the same rate as glycerol was supplied by the lipid emulsion (data not shown). Data are means, with standard errors represented by vertical bars. The NA and NA + glycerol groups did not differ significantly in any way. * Mean value was significantly different from those of the other groups $(P<0.05)$. (Redrawn from Moore et al. 2004.)

was infused via a peripheral vein, glucagon was replaced at basal rates via portal infusion, and insulin was infused intraportally at $0.6 \mathrm{mU} / \mathrm{kg}$ per min for $120 \mathrm{~min}($ period 1$)$ and then at $2.0 \mathrm{mU} / \mathrm{kg}$ per min for another $120 \mathrm{~min}$ (period 2). Glucose was infused via a peripheral vein as needed to maintain euglycaemia (6.1 mM) throughout periods 1 and 2. Arterial plasma insulin concentrations were similar throughout all periods in the two groups (36 (SE 6), 66 (SE 6), and 300 (SE 36) pmol/l during the basal period and periods 1 and 2, respectively, in the saline-infused group and 48 (SE 18),
60 (SE 6), and 276 (SE 12) pmol/l in the lipid-infused group). Net hepatic glucose output was no different in the two groups during the basal period, but the saline group shifted to net hepatic glucose uptake in period 1, while the lipid-infused group still exhibited net hepatic glucose output (Fig. 5; $P<0.05$ between groups). Arterial plasma NEFA concentrations tended to be higher throughout all periods in the lipid-infused dogs, but this did not reach statistical significance (Fig. 5). As evidenced by blood glycerol concentrations, lipolysis was significantly less suppressed at both steps of the insulin infusion in the dogs that had received the lipid infusions. Thus, the chronic postprandial NEFA elevation induced insulin resistance both at the liver and in the adipose tissue.
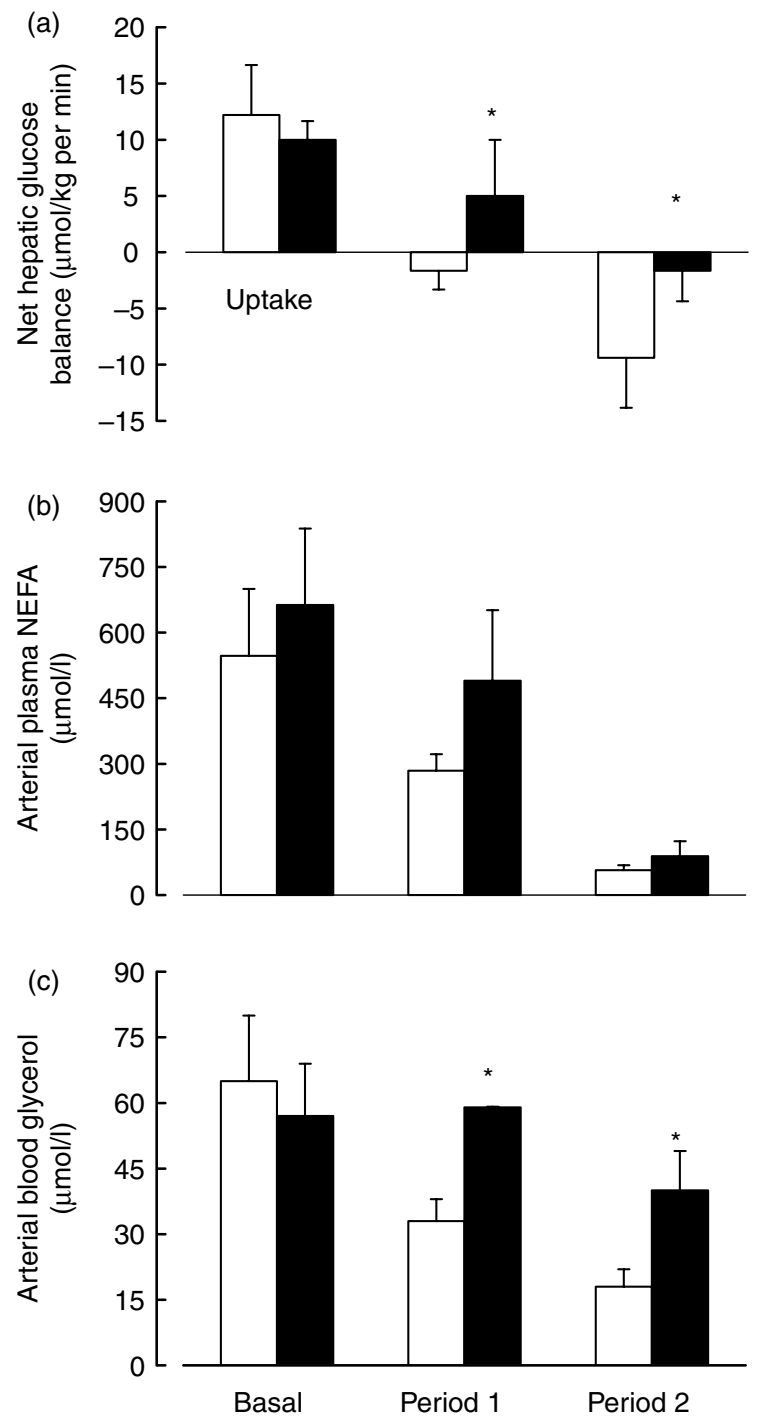

Fig. 5. Net hepatic glucose balance (a), NEFA levels (b) and glycerol concentrations (c) in the basal state and during a two-step hyperinsulinaemic-euglycaemic clamp in dogs chronically infused with saline $(\square)$ or a lipid emulsion ( $\square$ ) during the postprandial period. Data are means, with standard errors represented by vertical bars. * Mean value was significantly different from that of the saline-infused controls $(P<0.05)$. 
The findings in the dog are in general agreement with those from individuals with type 2 diabetes and normal volunteers receiving a mixed meal (Woerle et al. 2006). Neither the basal nor the postprandial NEFA concentrations differed between the two groups in that investigation. However, over the first 90 min of the postprandial period, NEFA declined significantly more slowly in the diabetic group. Tracerdetermined splanchnic glucose uptake did not differ between the groups, but endogenous glucose rate of appearance was suppressed significantly less in the diabetic group and therefore net splanchnic glucose uptake was impaired. As with NEFA, glycerol concentrations did not fall as rapidly in the postprandial period in the diabetic subjects, suggesting that lipolysis was not suppressed as rapidly.

\section{Conclusion}

The unique position of the liver gives it early exposure to absorbed nutrients, as well as to lipids released from visceral adipose. This allows the various substrates to modulate hepatic nutrient metabolism in a number of important ways. Hepatic glucose extraction is enhanced by enteral glucose delivery, which reduces the glucose that must be disposed of in the peripheral tissues and enhances hepatic glycogen synthesis. Similarly, amino acids reaching the liver via the portal vein appear to stimulate hepatic protein synthesis. Thus, although amino acid requirements may be lower during parenteral $v$. enteral nutrition, liver protein synthesis may not be stimulated as much during parenteral nutrition. Additionally, elevated lipid concentrations in the portal circulation may impair both hepatic and peripheral insulin sensitivity. Data clearly point to the route of delivery - portal $v$. peripheral - as being an important determinant of nutrient disposition in both hepatic and extra hepatic tissues. These findings have important implications for patients requiring nutrition support and those with increased nutrient needs.

\section{References}

Abumrad NN, Cherrington AD, Williams PE, Lacy WW \& Rabin D (1982) Absorption and disposition of a glucose load in the conscious dog. American Journal of Physiology 242, E398-E406.

Adkins BA, Myers SR, Hendrick GK, Stevenson RW, Williams PE \& Cherrington AD (1987) Importance of the route of intravenous glucose delivery to hepatic glucose balance in the conscious dog. Journal of Clinical Investigation 79, 557-565.

Adkins-Marshall B, Pagliassotti MJ, Asher JR, Connolly CC, Neal DW, Williams PE, Myers SR, Hendrick GK, Adkins RB Jr \& Cherrington AD (1992) Role of hepatic nerves in response of liver to intraportal glucose delivery in dogs. American Journal of Physiology 262, E679-E686.

Adkins-Marshall BA, Myers SR, Hendrick GK, Williams PE, Triebwasser K, Floyd B \& Cherrington AD (1990) Interaction between insulin and glucose-delivery route in regulation of net hepatic glucose uptake in conscious dogs. Diabetes 39, 87-95.

Agius L (1994) Control of glucokinase translocation in rat hepatocytes by sorbitol and the cytosolic redox state. Biochemical Journal 298, 237-243.

Agius L \& Peak M (1993) Intracellular binding of glucokinase in hepatocytes and translocation by glucose, fructose and insulin. Biochemical Journal 296, 785-796.
Ahlman B, Charlton M, Fu A, Berg C, O’Brien P \& Nair KS (2001) Insulin's effect on synthesis rates of liver proteins. A swine model comparing various precursors of protein synthesis. Diabetes 50, 947-954.

Andersen DK, Ruiz CL \& Burant CF (1994) Insulin regulation of hepatic glucose transporter protein is impaired in chronic pancreatitis. Annals of Surgery 219, 679-686; discussion 686-677.

Arnal MA, Mosoni L, Boirie Y, et al. (2000). Protein feeding pattern does not affect protein retention in young women. Journal of Nutrition 130, 1700-1704.

Balage M, Sinaud S, Prod'homme M, Dardevet D, Vary TC, Kimball SR, Jefferson LS \& Grizard J (2001) Amino acids and insulin are both required to regulate assembly of the eIF4E.eIF4G complex in rat skeletal muscle. American Journal of Physiology 281, E565-E574.

Ballmer PE, McNurlan MA, Essen P, Anderson SE \& Garlick PJ (1995) Albumin synthesis rates measured with [2H5ring]phenylalanine are not responsive to short-term intravenous nutrients in healthy humans. Journal of Nutrition 125, 512-519.

Barle H, Nyberg B, Essen P, Andersson K, McNurlan MA, Wernerman J \& Garlick PJ (1997) The synthesis rates of total liver protein and plasma albumin determined simultaneously in vivo in humans. Hepatology 25, 154-158.

Barrett EJ, Bevilacqua S, DeFronzo RA \& Ferrannini E (1994) Glycogen turnover during refeeding in the postabsorptive dog: implications for the estimation of glycogen formation using tracer methods. Metabolism 43, 285-292.

Barrett EJ, Ferrannini E, Gusberg R, Bevilacqua S \& DeFronzo RA (1985) Hepatic and extrahepatic splanchnic glucose metabolism in the postabsorptive and glucose fed dog. Metabolism 34, $410-420$.

Basu A, Basu R, Shah P, Vella A, Johnson CM, Nair KS, Jensen MD, Schwenk WF \& Rizza RA (2000) Effects of type 2 diabetes on the ability of insulin and glucose to regulate splanchnic and muscle glucose metabolism: evidence for a defect in hepatic glucokinase activity. Diabetes 49, 272-283.

Benn JJ, Bozzard SJ, Kelley D, Mitrakou A, Aoki T, Sorensen J, Gerich J \& Sonksen PH (1989) Persistent abnormalities of the metabolism of an oral glucose load in insulin-treated type I diabetics. Metabolism 38, 1047-1055.

Bergman RN, Beir JR \& Hourigan PM (1982) Intraportal glucose infusion matched to oral glucose absorption. Lack of evidence for "gut factor" involvement in hepatic glucose storage. Diabetes 31, 27-35.

Berthold HK, Jahoor F, Klein PD \& Reeds PJ (1995) Estimates of the effect of feeding on whole-body protein degradation in women vary with the amino acid used as tracer. Journal of Nutrition 125, 2516-2527.

Bertolo RF, Chen CZ, Law G, Pencharz PB \& Ball RO (1998) Threonine requirement of neonatal piglets receiving total parenteral nutrition is considerably lower than that of piglets receiving an identical diet intragastrically. Journal of Nutrition 128, 1752-1759.

Biolo G, Tessari P, Inchiostro S, Bruttomesso D, Fongher C, Sabadin L, Fratton MG, Valerio A \& Tiengo A (1992) Leucine and phenylalanine kinetics during mixed meal ingestion: a multiple tracer approach. American Journal of Physiology 262, E455-E463.

Boden G, Cheung P, Stein TP, Kresge K \& Mozzoli M (2002) FFA cause hepatic insulin resistance by inhibiting insulin suppression of glycogenolysis. American Journal of Physiology 283, E12-E19.

Boirie Y, Gachon P, Corny S, Fauquant J, Maubois JL \& Beaufrere B (1996). Acute postprandial changes in leucine metabolism as assessed with an intrinsically labeled milk protein. American Journal of Physiology 271, E1083-E1091. 
Boirie Y, Gachon P \& Beaufrere B (1997) Splanchnic and wholebody leucine kinetics in young and elderly men. American Journal of Clinical Nutrition 65, 489-495.

Bollen M, Keppens S \& Stalmans W (1998) Specific features of glycogen metabolism in the liver. Biochemical Journal 336, $19-31$.

Bolster DR, Jefferson LS \& Kimball SR (2004) Regulation of protein synthesis associated with skeletal muscle hypertrophy by insulin-, amino acid- and exercise-induced signalling. Proceedings of the Nutrition Society 63, 351-356.

Burrin DG \& Davis TA (2004) Proteins and amino acids in enteral nutrition. Current Opinion in Clinical Nutrition and Metabolic Care 7, 79-87.

Cardin S, Pagliassotti MJ, Moore MC, Edgerton DS, Lautz M, Farmer B, Neal DW \& Cherrington AD (2004) Vagal cooling and concomitant portal norepinephrine infusion do not reduce net hepatic glucose uptake in the conscious dog. American Journal of Physiology 287, R742-R748.

Cayol M, Boirie Y, Prugnaud J, Gachon P, Beaufrere B \& Obled C (1996) Precursor pool for hepatic protein synthesis in humans: effects of tracer route infusion and dietary proteins. American Journal of Physiology 270, E980-E987.

Cayol M, Boirie Y, Rambourdin F, Prugnaud J, Gachon P, Beaufrere B \& Obled C (1997) Influence of protein intake on whole body and splanchnic leucine kinetics in humans. American Journal of Physiology 272, E584-E591.

Chap Z, Ishida T, Chou J, Lewis R, Hartley C, Entman M \& Field JB (1985) Effects of atropine and gastric inhibitory polypeptide on hepatic glucose uptake and insulin extraction in conscious dogs. Journal of Clinical Investigation 76, $1174-1181$.

Chen SS, Torres-Sanchez CJ, Hosein N, Zhang Y, Lacy DB, Chang C \& McGuinness OP (2005) Route-dependent effect of nutritional support on liver glucose uptake. American Journal of Physiology 289, R1319-R1327.

Cherrington AD (1999) Banting Lecture 1997. Control of glucose uptake and release by the liver in vivo. Diabetes 48, 1198-1214.

Cherrington AD, Liljenquist JE, Shulman GI, Williams PE \& Lacy WW (1979) Importance of hypoglycemia-induced glucose production during isolated glucagon deficiency. American Journal of Physiology 236, E263-E271.

Cherrington AD, Williams PE, Abou-Mourad N, Lacy WW, Steiner KE \& Liljenquist JE (1982) Insulin as a mediator of hepatic glucose uptake in the conscious dog. American Journal of Physiology 242, E97-E101.

Chu CA, Fujimoto Y, Igawa K, Grimsby J, Grippo JF, Magnuson MA, Cherrington AD \& Shiota M (2004) Rapid translocation of hepatic glucokinase in response to intraduodenal glucose infusion and changes in plasma glucose and insulin in conscious rats. American Journal of Physiology 286, G627-G634.

Cline GW, Rothman DL, Magnusson I, Katz LD \& Shulman GI (1994) ${ }^{13}$ C-nuclear magnetic resonance spectroscopy studies of hepatic glucose metabolism in normal subjects and subjects with insulin-dependent diabetes mellitus. Journal of Clinical Investigation 94, 2369-2376.

Dardevet D, Sornet C, Balage M \& Grizard J (2000) Stimulation of in vitro rat muscle protein synthesis by leucine decreases with age. Journal of Nutrition 130, 2630-2635.

Dardevet D, Sornet C, Bayle G, Prugnaud J, Pouyet C \& Grizard J (2002) Postprandial stimulation of muscle protein synthesis in old rats can be restored by a leucine-supplemented meal. Journal of Nutrition 132, 95-100.

Davis TA, Fiorotto ML, Burrin DG, Reeds PJ, Nguyen HV, Beckett PR, Vann RC \& O'Connor PM (2002) Stimulation of protein synthesis by both insulin and amino acids is unique to skeletal muscle in neonatal pigs. American Journal of Physiology 282, E880-E890.
De Feo P, Horber FF \& Haymond MW (1992) Meal stimulation of albumin synthesis: a significant contributor to whole body protein synthesis in humans. American Journal of Physiology 263, E794-E799.

De Feo P \& Lucidi P (2002) Liver protein synthesis in physiology and in disease states. Current Opinion in Clinical Nutrition and Metabolic Care 5, 47-50.

DeFronzo RA, Ferrannini E, Hendler R, Felig P \& Wahren J (1983) Regulation of splanchnic and peripheral glucose uptake by insulin and hyperglycemia in man. Diabetes 32, 35-45.

DeFronzo RA, Ferrannini E, Hendler R, Wahren J \& Felig P (1978) Influence of hyperinsulinemia, hyperglycemia, and the route of glucose administration on splanchnic glucose exchange. Proceedings of the National Academy of Sciences USA 75, 5173-5177.

Detheux M \& van Schaftingen E (1994) Heterologous expression of an active rat regulatory protein of glucokinase. FEBS Letters 355, 27-29.

DiCostanzo CA, Dardevet D, Neal DW, Lautz M, Allen E, Snead W \& Cherrington AD (2006) Role of the hepatic sympathetic nerves in the regulation of net hepatic glucose uptake and the mediation of the portal glucose signal. American Journal of Physiology 290, E9-E16.

Dunning BE, Moore MC, Ikeda T, Neal DW, Scott MF \& Cherrington AD (2002) Portal glucose infusion exerts an incretin effect associated with changes in pancreatic neural activity in conscious dogs. Metabolism 51, 1324-1330.

Elango R, Pencharz PB \& Ball RO (2002) The branched-chain amino acid requirement of parenterally fed neonatal piglets is less than the enteral requirement. Journal of Nutrition 132, 3123-3129.

Everett CA, Rivera N, Rodewald T, Neal D, Donahue EP, Williams PE \& Cherrington AD (2005) Chronic postprandial intraportal infusion of FFA results in hepatic and adipose tissue insulin resistance. Diabetes 54, A329.

Felig P, Wahren J \& Hendler R (1975) Influence of oral glucose ingestion on splanchnic glucose and gluconeogenic substrate metabolism in man. Diabetes 24, 468-475.

Felig P, Wahren J \& Hendler R (1978) Influence of maturity-onset diabetes on splanchnic glucose balance after oral glucose ingestion. Diabetes 27, 121-126.

Ferrannini E, Bjorkman O, Reichard GA Jr, Pilo A, Olsson M, Wahren J \& DeFronzo RA (1985) The disposal of an oral glucose load in healthy subjects. A quantitative study. Diabetes 34, 580-588.

Ferrannini E, DeFronzo RA, Gusberg R, Tepler J, Jacob R, Aaron M, Smith D \& Barrett EJ (1988) Splanchnic amino acid and glucose metabolism during amino acid infusion in dogs. Diabetes 37, 237-245.

Fery F, Deviere J \& Balasse EO (2001) Metabolic handling of intraduodenal vs. intravenous glucose in humans. American Journal of Physiology 281, E261-E268.

Fery F, Tappy L, Deviere J \& Balasse EO (2004) Comparison of intraduodenal and intravenous glucose metabolism under clamp conditions in humans. American Journal of Physiology 286, E176-E183.

Firth RG, Bell PM, Marsh HM, Hansen I \& Rizza RA (1986) Postprandial hyperglycemia in patients with noninsulindependent diabetes mellitus. Role of hepatic and extrahepatic tissues. Journal of Clinical Investigation 77, 1525-1532.

Frizzell RT, Hendrick GK, Biggers DW, Lacy DB, Donahue DP, Green DR, Carr RK, Williams PE, Stevenson RW \& Cherrington AD (1988) Role of gluconeogenesis in sustaining glucose production during hypoglycemia caused by continuous insulin infusion in conscious dogs. Diabetes 37, 749-759.

Galassetti P, Chu CA, Neal DW, Reed GW, Wasserman DH \& Cherrington AD (1999) A negative arterial-portal venous 
glucose gradient increases net hepatic glucose uptake in euglycemic dogs. American Journal of Physiology 277, E126-E134.

Galassetti P, Shiota M, Zinker BA, Wasserman DH \& Cherrington AD (1998) A negative arterial-portal venous glucose gradient decreases skeletal muscle glucose uptake. American Journal of Physiology 275, E101-E111.

Garlick PJ, Fern M \& Preedy VR (1983) The effect of insulin infusion and food intake on muscle protein synthesis in postabsorptive rats. Biochemical Journal 210, 669-676.

Holste LC, Connolly CC, Moore MC, Neal DW \& Cherrington AD (1997) Physiological changes in circulating glucagon alter hepatic glucose disposition during portal glucose delivery. American Journal of Physiology 273, E488-E496.

Homko CJ, Cheung P \& Boden G (2003) Effects of free fatty acids on glucose uptake and utilization in healthy women. Diabetes 52, 487-491.

House JD, Pencharz PB \& Ball RO (1998) Lysine requirement of neonatal piglets receiving total parenteral nutrition as determined by oxidation of the indicator amino acid L- $\left[1-{ }^{14} \mathrm{C}\right]$ phenylalanine. American Journal of Clinical Nutrition 67, 67-73.

Hsieh PS, Moore MC, Neal DW \& Cherrington AD (1998) Hepatic glucose uptake rapidly decreases after removal of the portal signal in conscious dogs. American Journal of Physiology 275, E987-E992.

Hsieh PS, Moore MC, Neal DW, Emshwiller M \& Cherrington AD (1999) Rapid reversal of the effects of the portal signal under hyperinsulinaemic conditions in the conscious dog. American Journal of Physiology 276, E930-E937.

Hunter KA, Ballmer PE, Anderson SE, Broom J, Garlick PJ \& McNurlan MA (1995) Acute stimulation of albumin synthesis rate with oral meal feeding in healthy subjects measured with [ring-2H5]phenylalanine. Clinical Science (London) 88, $235-242$.

Ishida T, Chap Z, Chou J, Lewis R, Hartley C, Entman M \& Field JB (1983) Differential effects of oral, peripheral intravenous, and intraportal glucose on hepatic glucose uptake and insulin and glucagon extraction in conscious dogs. Journal of Clinical Investigation 72, 590-601.

Kawamori R, Morishima T, Ikeda M, Kubota M, Kishimoto M, Shiba Y, Matsuhisa M, Kodama M, Watarai T, et al. (1994) Effect of strict metabolic control on glucose handling by the liver and peripheral tissues in non-insulin-dependent diabetes mellitus. Diabetes Research and Clinical Practice 23, 155-161.

Kelley D, Mokan M \& Veneman T (1994) Impaired postprandial glucose utilization in non-insulin-dependent diabetes mellitus. Metabolism 43, 1549-1557.

Lautt WW (1983) Afferent and efferent neural roles in liver function. Progress in Neurobiology 21, 323-348.

Lautt WW (2004) A new paradigm for diabetes and obesity: the hepatic insulin sensitizing substance (HISS) hypothesis. Journal of Pharmacological Science 95, 9-17.

Liu Z, Gardner LB \& Barrett EJ (1993) An endogenous glycogenassociated compound modulates glucose-6-phosphatase activity in rat liver microsomes. Biochemical and Biophysical Research Communications 195, 173-178.

Ludvik B, Nolan JJ, Roberts A, Baloga J, Joyce M, Bell JM \& Olefsky JM (1997) Evidence for decreased splanchnic glucose uptake after oral glucose administration in non-insulindependent diabetes mellitus. Journal of Clinical Investigation 100, 2354-2361.

McGuinness OP, Friedman A \& Cherrington AD (1990) Intraportal hyperinsulinemia decreases insulin-stimulated glucose uptake in the dog. Metabolism 39, 127-132.

Mari A, Wahren J, DeFronzo RA \& Ferrannini E (1994) Glucose absorption and production following oral glucose: comparison of compartmental and arteriovenous-difference methods. Metabolism 43, 1419-1425.

Matthews DE, Marano MA \& Campbell RG (1993) Splanchnic bed utilization of leucine and phenylalanine in humans. American Journal of Physiology 264, E109-E118.

Meek SE, Nair KS \& Jensen MD (1999) Insulin regulation of regional free fatty acid metabolism. Diabetes 48, 10-14.

Minokoshi Y, Okano Y \& Shimazu T (1994) Regulatory mechanism of the ventromedial hypothalamus in enhancing glucose uptake in skeletal muscles. Brain Research 649, 343-347.

Moore MC, Cherrington AD, Cline G, Pagliassotti MJ, Jones EM, Neal DW, Badet C \& Shulman GI (1991) Sources of carbon for hepatic glycogen synthesis in the conscious dog. Journal of Clinical Investigation 88, 578-587.

Moore MC, Flakoll PJ, Hsieh PS, Pagliassotti MJ, Neal DW, Monohan MT, Venable C \& Cherrington AD (1998) Hepatic glucose disposition during concomitant portal glucose and amino acid infusions in the dog. American Journal of Physiology 274, E893-E902.

Moore MC, Hsieh PS, Flakoll PJ, Neal DW \& Cherrington AD (1999a) Differential effect of amino acid infusion route on net hepatic glucose uptake in the dog. American Journal of Physiology 276, E295-E302.

Moore MC, Hsieh PS, Flakoll PJ, Neal DW \& Cherrington AD (1999b) Net hepatic gluconeogenic amino acid uptake in response to peripheral versus portal amino acid infusion in conscious dogs. Journal of Nutrition 129, 2218-2224.

Moore MC, Pagliassotti MJ, Swift LL, Asher J, Murrell J, Neal D $\&$ Cherrington AD (1994) Disposition of a mixed meal by the conscious dog. American Journal of Physiology 266, E666-E675.

Moore MC, Satake S, Lautz M, Soleimanpour SA, Neal DW, Smith M \& Cherrington AD (2004) Nonesterified fatty acids and hepatic glucose metabolism in the conscious dog. Diabetes $\mathbf{5 3}$, 32-40.

Mosoni L, Patureau Mirand P, Houlier ML \& Arnal M (1993) Agerelated changes in protein synthesis measured in vivo in rat liver and gastrocnemius muscle. Mechanisms of Ageing and Development 68, 209-220.

Mosoni L, Valluy MC, Serrurier B, Prugnaud J, Obled C, Guezennec CY \& Mirand PP (1995) Altered response of protein synthesis to nutritional state and endurance training in old rats. American Journal of Physiology 268, E328-E335.

Myers SR, Biggers DW, Neal DW \& Cherrington AD (1991a) Intraportal glucose delivery enhances the effects of hepatic glucose load on net hepatic glucose uptake in vivo. Journal of Clinical Investigation 88, 158-167.

Myers SR, Diamond MP, Adkins-Marshall BA, Williams PE, Stinsen R \& Cherrington AD (1991b) Effects of small changes in glucagon on glucose production during a euglycemic, hyperinsulinemic clamp. Metabolism 40, 66-71.

Myers SR, McGuinness OP, Neal DW \& Cherrington AD (1991c) Intraportal glucose delivery alters the relationship between net hepatic glucose uptake and the insulin concentration. Journal of Clinical Investigation 87, 930-939.

Nauck MA, Homberger E, Siegel EG, Allen RC, Eaton RP, Ebert R \& Creutzfeldt W (1986) Incretin effects of increasing glucose loads in man calculated from venous insulin and C-peptide responses. Journal of Clinical Endocrinology and Metabolism 63, 492-498.

Niijima A (1982) Glucose-sensitive afferent nerve fibres in the hepatic branch of the vagus nerve in the guinea-pig. Journal of Physiology 332, 315-323.

Niijima A (1983) Glucose-sensitive afferent nerve fibers in the liver and their role in food intake and blood glucose regulation. Journal of the Autonomic Nervous System 9, 207-220. 
Niijima A (1984) Reflex control of the autonomic nervous system activity from the glucose sensors in the liver in normal and midpontine-transected animals. Journal of the Autonomic Nervous System 10, 279-285.

Niijima A (1985) Blood glucose levels modulate efferent activity in the vagal supply to the rat liver. Journal of Physiology 364, $105-112$.

Niijima A \& Meguid MM (1994) Parenteral nutrients in rat suppresses hepatic vagal afferent signals from portal vein to hypothalamus. Surgery 116, 294-301.

Niijima A \& Meguid MM (1995) An electrophysiological study on amino acid sensors in the hepato-portal system in the rat. Obesity Research 3, Suppl. 5, 741S-745S.

Nygren J \& Nair KS (2003) Differential regulation of protein dynamics in splanchnic and skeletal muscle beds by insulin and amino acids in healthy human subjects. Diabetes 52, $1377-1385$.

O'Connor PM, Bush JA, Suryawan A, Nguyen HV \& Davis TA (2003a) Insulin and amino acids independently stimulate skeletal muscle protein synthesis in neonatal pigs. American Journal of Physiology 284, E110-E119.

O'Connor PM, Kimball SR, Suryawan A, Bush JA, Nguyen HV, Jefferson LS \& Davis TA (2003b) Regulation of translation initiation by insulin and amino acids in skeletal muscle of neonatal pigs. American Journal of Physiology 285, E40-E53.

Pacy PJ, Price GM, Halliday D, Quevedo MR \& Millward DJ (1994). Nitrogen homeostasis in man: the diurnal responses of protein synthesis and degradation and amino acid oxidation to diets with increasing protein intakes. Clin Sci (Lond), 86, $103-116$.

Pagliassotti MJ, Holste LC, Moore MC, Neal DW \& Cherrington AD (1996) Comparison of the time courses of insulin and the portal signal on hepatic glucose and glycogen metabolism in the conscious dog. Journal of Clinical Investigation 97, 81-91.

Pehling G, Tessari P, Gerich JE, Haymond MW, Service FJ \& Rizza RA (1984) Abnormal meal carbohydrate disposition in insulin-dependent diabetes. Relative contributions of endogenous glucose production and initial splanchnic uptake and effect of intensive insulin therapy. Journal of Clinical Investigation 74, 985-991.

Perrin C, Knauf C \& Burcelin R (2004) Intracerebroventricular infusion of glucose, insulin, and the adenosine monophosphateactivated kinase activator, 5-aminoimidazole-4-carboxamide-1beta-D-ribofuranoside, controls muscle glycogen synthesis. Endocrinology 145, 4025-4033.

Prod'homme M, Balage M, Debras E, Farges MC, Kimball S, Jefferson L \& Grizard J (2004) Differential effects of insulin and dietary amino acids on muscle protein synthesis in adult and old rats. Journal of Physiology 563, 235-248.

Puschel GP (2004) Control of hepatocyte metabolism by sympathetic and parasympathetic hepatic nerves. The Anatomical Record 280A, 854-867.

Radziuk J (1989) Hepatic glycogen in humans. I. Direct formation after oral and intravenous glucose or after a 24-h fast. American Journal of Physiology 257, E145-E157.

Reaven GM (2005) Compensatory hyperinsulinemia and the development of an atherogenic lipoprotein profile: the price paid to maintain glucose homeostasis in insulin-resistant individuals. Endocrinology and Metabolism Clinics of North America 34, 49-62.

Reaven GM, Hollenbeck C, Jeng CY, Wu MS \& Chen YD (1988) Measurement of plasma glucose, free fatty acid, lactate, and insulin for $24 \mathrm{~h}$ in patients with NIDDM. Diabetes 37, 1020-1024.

Rennie MJ, Edwards RH, Halliday D, Matthews DE, Wolman SL \& Millward DJ (1982). Muscle protein synthesis measured by stable isotope techniques in man: the effects of feeding and fasting. Clin Sci (Lond), 63, 519-523.

Russek M (1963) Participation of hepatic glucoreceptors in the control of intake of food. Nature 197, 79-80.

Russek M (1981) Current status of the hepatostatic theory of food intake control. Appetite 2, 137-143.

Scheen AJ \& Luyckx FH (2002) Obesity and liver disease. Best Practice and Research. Clinical Endocrinology and Metabolism 16, 703-716.

Schmitt M (1973) Influences of hepatic portal receptors on hypothalamic feeding and satiety centers. American Journal of Physiology 225, 1089-1095.

Shimazu T (1967) Glycogen synthetase activity in liver: regulation by the autonomic nerves. Science 156, 1256-1257.

Shimazu T (1971) Regulation of glycogen metabolism in liver by the autonomic nervous system. V. Activation of glycogen synthetase by vagal stimulation. Biochimica et Biophysica Acta 252, 28-38.

Shimazu T (1987) Neuronal regulation of hepatic glucose metabolism in mammals. Diabetes/Metabolism Reviews 3, 185-206.

Shimazu T \& Fujimoto T (1971) Regulation of glycogen metabolism in liver by the autonomic nervous system. IV. Neural control of glycogen biosynthesis. Biochimica et Biophysica Acta 252, 18-27.

Shiota M, Galassetti P, Monohan M, Neal DW \& Cherrington AD (1998) Small amounts of fructose markedly augment net hepatic glucose uptake in the conscious dog. Diabetes 47, 867-873.

Shiota M, Jackson P, Galassetti P, Scott M, Neal DW \& Cherrington AD (2000) Combined intraportal infusion of acetylcholine and adrenergic blockers augments net hepatic glucose uptake. American Journal of Physiology 278, E544-E552.

Shoveller AK, Brunton JA, Pencharz PB \& Ball RO (2003) The methionine requirement is lower in neonatal piglets fed parenterally than in those fed enterally. Journal of Nutrition 133, 1390-1397.

Shulman GI, Liljenquist JE, Williams PE \& Lacy WW (1978) Glucose disposal during insulinopenia in somatostatin-treated dogs. The roles of glucose and glucagon. Journal of Clinical Investigation 62, 487-491.

Shulman GI, Rossetti L, Rothman DL, Blair JB \& Smith D (1987) Quantitative analysis of glycogen repletion by nuclear magnetic resonance spectroscopy in the conscious rat. Journal of Clinical Investigation 80, 387-393.

Sindelar DK, Chu CA, Rohlie M, Neal DW, Swift LL \& Cherrington AD (1997) The role of fatty acids in mediating the effects of peripheral insulin on hepatic glucose production in the conscious dog. Diabetes 46, 187-196.

Stoll B, Burrin DG, Henry J, Yu H, Jahoor F \& Reeds PJ (1998) Dietary amino acids are the preferential source of hepatic protein synthesis in piglets. Journal of Nutrition 128, 1517-1524.

Stumpel F \& Jungermann K (1997) Sensing by intrahepatic muscarinic nerves of a portal-arterial glucose concentration gradient as a signal for insulin-dependent glucose uptake in the perfused rat liver. FEBS Letters 406, 119-122.

Svanberg E, Jefferson LS, Lundholm K \& Kimball SR (1997) Postprandial stimulation of muscle protein synthesis is independent of changes in insulin. American Journal of Physiology 272, E841-E847.

Thorne A, Lonnqvist F, Apelman J, Hellers G \& Arner P (2002) A pilot study of long-term effects of a novel obesity treatment: omentectomy in connection with adjustable gastric banding. International Journal of Obesity and Related Metabolic Disorders 26, 193-199.

van Schaftingen E (1994) Short-term regulation of glucokinase. Diabetologia 37, Suppl. 2, S43-S47.

Vella A, Shah P, Basu R, Basu A, Camilleri M, Schwenk WF \& Rizza RA (2002) Effect of enteral vs. parenteral glucose delivery 
on initial splanchnic glucose uptake in nondiabetic humans. American Journal of Physiology 283, E259-E266.

Volpi E, Lucidi P, Cruciani G, Monacchia F, Reboldi G, Brunetti P, Bolli GB \& De Feo P (1996) Contribution of amino acids and insulin to protein anabolism during meal absorption. Diabetes 45, 1245-1252.

Volpi E, Mittendorfer B, Wolf SE \& Wolfe RR (1999) Oral amino acids stimulate muscle protein anabolism in the elderly despite higher first-pass splanchnic extraction. American Journal of Physiology 277, E513-E520.

Watanabe Y, Takahashi A \& Shimazu T (1990) Neural control of biosynthesis and secretion of serum transferrin in perfused rat liver. Biochemical Journal 267, 545-548.
Weinstein SP, O'Boyle E, Fisher M \& Haber RS (1994) Regulation of GLUT2 glucose transporter expression in liver by thyroid hormone: evidence for hormonal regulation of the hepatic glucose transport system. Endocrinology 135, 649-654.

Woerle HJ, Szoke E, Meyer C, Dostou JM, Wittlin SD, Gosmanov NR, Welle SL \& Gerich JE (2006) Mechanisms for abnormal postprandial glucose metabolism in type 2 diabetes. American Journal of Physiology 290, E67-E77.

Yoshizawa F, Kimball SR \& Jefferson LS (1997) Modulation of translation initiation in rat skeletal muscle and liver in response to food intake. Biochemical and Biophysical Research Communications 240, 825-831. 